\title{
Reduced culture temperature attenuates oxidative stress and inflammatory response facilitating expansion and differentiation of adipose-derived stem cells
}

Gal Tirza ${ }^{1 \dagger}$, Inna Solodeev ${ }^{1 \dagger}$, Meirav Sela ${ }^{1}$, Ilanit Greenberg ${ }^{1}$, Metsada Pasmanik-Chor ${ }^{2}$, Eyal Gur ${ }^{3}$ and Nir Shani ${ }^{3^{*}}$ (D)

\begin{abstract}
Background: Adipose-derived stem cell (ASC) expansion under atmospheric oxygen levels (21\%) was previously shown to cause increased reactive oxygen species (ROS) accumulation and genetic instability compared to cells cultured under physiological oxygen levels (2-8\%). However, since culture under physiological oxygen levels is costly and complicated, a simpler method to reduce ROS accumulation is desirable. The current study aimed to determine whether lower culture temperature can reduce ROS production in ASCs without impairing their culture expansion.
\end{abstract}

Methods: Proliferation, differentiation, ROS accumulation, and gene expression were compared between ASC cultures at $35^{\circ} \mathrm{C}$ and $37^{\circ} \mathrm{C}$. ASCs isolated either from rat fat depots or from human lipoaspirates were examined in the study.

Results: Rat visceral ASCs (vASCs) cultured at $35^{\circ} \mathrm{C}$ demonstrated reduced ROS production and apoptosis and enhanced expansion and adipogenic differentiation compared to vASCs cultured at $37^{\circ} \mathrm{C}$. Similarly, the culture of human ASCs (hASCs) at $35^{\circ} \mathrm{C}$ led to reduced ROS accumulation and apoptosis, with no effect on the proliferation rate, compared to hASCs cultured at $37^{\circ} \mathrm{C}$. Comparison of gene expression profiles of $35^{\circ} \mathrm{C}$ versus $37^{\circ} \mathrm{C}$ vASCs uncovered the development of a pro-inflammatory phenotype in $37^{\circ} \mathrm{C}$ vASCs in correlation with culture temperature and ROS overproduction. This correlation was reaffirmed in both hASCs and subcutaneous rat ASCs.

Conclusions: This is the first evidence of the effect of culture temperature on ASC growth and differentiation properties. Reduced temperatures may result in superior ASC cultures with enhanced expansion capacities in vitro and effectiveness in vivo.

\section{Introduction}

Mesenchymal stem cells (MSCs) are multipotent, can be derived from most adult tissues, and have been demonstrated to bear regenerative and immunosuppressive capacities in preclinical models [1]. Although first isolated from the bone marrow, MSCs were also later isolated from adipose tissue and termed adipose-derived stem cells (ASCs) [2, 3]. Clinical utilization of MSCs often requires

\footnotetext{
* Correspondence: nirs@tlvmc.gov.il

${ }^{\dagger}$ Gal Tirza and Inna Solodeev contributed equally to this work.

${ }^{3}$ The Department of Plastic and Reconstructive Surgery, Tel Aviv Sourasky Medical Center, affiliated with the Sackler Faculty of Medicine, Tel Aviv University, Weizmann 6, Tel Aviv, Israel

Full list of author information is available at the end of the article
}

$1 \times 10^{6}-5 \times 10^{6}$ cells $/ \mathrm{kg}$ [4] necessitating significant in vitro expansion of cells prior to their application, increasing the risk of DNA mutation and genetic instability.

Reactive oxygen species (ROS) are a byproduct of mitochondrial oxidative phosphorylation but are also generated as cellular signaling molecules by enzymes such as the family of NOX NADPH oxidases [5]. ROS overproduction leads to various destructive cellular processes, such as aging, DNA damage, and apoptosis [6, 7]. Physiological oxygen levels within the MSC niche were reported to be between 2 and 8\% [8]. Elevated oxygen concentrations stimulate increased mitochondrial ROS production by promoting higher ROS leakage from the respiratory chain [9]. Consequently, MSC culture at drastically higher

(c) The Author(s). 2020 Open Access This article is distributed under the terms of the Creative Commons Attribution 4.0 International License (http://creativecommons.org/licenses/by/4.0/), which permits unrestricted use, distribution, and reproduction in any medium, provided you give appropriate credit to the original author(s) and the source, provide a link to the Creative Commons license, and indicate if changes were made. The Creative Commons Public Domain Dedication waiver (http://creativecommons.org/publicdomain/zero/1.0/) applies to the data made available in this article, unless otherwise stated. 
atmospheric oxygen levels (21\%), most commonly employed in culture protocols, leads to ROS overproduction, DNA damage, and genetic instability compared to culture under physiological oxygen levels (2-8\%) [10-14]. Culture under physiological oxygen conditions also leads to increased proliferation and stem cell potency of both pluripotent [15-17] and adult stem cells [18-24]. Although adaptation of culture conditions to physiological oxygen levels to prevent excess ROS is appealing, reducing oxygen levels from atmospheric levels is demanding and pricy and requires specialized equipment. Thus, simpler and most cost-effective approaches are desirable [25].

Reduced ROS production can theoretically be achieved by decreasing cellular temperature and consequently reducing cellular metabolism and mitochondrial oxygen consumption. Indeed, reduction of body temperature to mild hypothermia was demonstrated to protect against ischemiainduced cardiac damage and stroke [26-28] and to reduce ROS production and NOX activation following stroke [26, 29]. Decreased body temperature was also found to prevent ischemia-induced damage in hibernating animals [30]. This protection results, most probably, from metabolism reduction during hibernation, which leads to reduced mitochondrial activity and reduced ROS production [31, 32].

The effect of low temperature on cellular metabolism is also evident in cultured cells, with various cell types demonstrating lower cellular metabolism in correlation with temperature reduction [33-36]. However, decreased culture temperature also leads to a temperature-dependent reduction in cell proliferation in different cell types [3539]. For example, the culture of bone marrow-derived MSCs at $32{ }^{\circ} \mathrm{C}$ was demonstrated to attenuate ROS accumulation and apoptosis but also cell proliferation [38]. In contrast, long-term bone marrow cultures, first achieved when mesenchymal cells were used to form a niche for hematopoietic stem cells, demonstrated improved culture longevity and hematopoietic cell yields at $33^{\circ} \mathrm{C}$, as compared to the conventional culture conditions of $37^{\circ} \mathrm{C}$ [40].

The aim of the current study was to examine whether lowering culture temperature can inhibit the development of oxidative stress and its accompanying phenotype in ASC cultures without hindering their proliferation capacity. We hypothesized that only mildly reducing culture temperature to $35^{\circ} \mathrm{C}$ may reduce ROS production in ASCs without hindering their proliferation capacity. Proliferation, differentiation, ROS accumulation, and gene expression were therefore compared between ASC cultures at $35^{\circ} \mathrm{C}$ and $37^{\circ} \mathrm{C}$.

\section{Methods}

Human primary stromal vascular fraction (SVF) cell isolation

Subcutaneous adipose tissue samples were obtained from patients undergoing plastic surgery. All procedures were performed in accordance with the Declaration of Helsinki and approved by the ethics committee of Tel Aviv Sourasky Medical Center. Written, informed consent was obtained from all patients in advance. All samples were waste materials collected as a byproduct of surgery.

\section{Cell culture of human ASCs}

Human primary SVF cells from adipose tissue were maintained in their undifferentiated state in highglucose Dulbecco's modified Eagle's medium (DMEM) (Gibco, Paisley, Scotland, UK), supplemented with 10\% fetal calf serum (FCS) (Thermo Scientific HyClone, New Zealand), $60 \mu \mathrm{g} / \mathrm{ml}$ penicillin, $100 \mu \mathrm{g} / \mathrm{ml}$ streptomycin, $50 \mu \mathrm{g} / \mathrm{ml}$ kanamycin, $1 \mathrm{mM}$ sodium pyruvate, $2 \mathrm{mM} \mathrm{L-}$ glutamine, and non-essential amino acids, under $10 \%$ $\mathrm{CO}_{2}$ and atmospheric oxygen conditions at $37^{\circ} \mathrm{C}$. The medium was changed twice a week, and cells were passaged once they reached confluence.

\section{Mild hypothermia}

Cells were cultured in the medium described above, under atmospheric oxygen, at $35^{\circ} \mathrm{C}$.

\section{Cell culture of rat ASCs}

ASCs were derived from the adipose tissues of Lewis rats (purchased from the Harlan Laboratories Jerusalem, Israel). Cells were isolated from the surgically removed visceral or subcutaneous fat tissue, using $0.1 \%$ collagenase (Sigma), and separated from the fat by centrifugation. The cells were cultured in high-glucose DMEM (Gibco), supplemented with 10\% FCS (Thermo Scientific HyClone), $60 \mu \mathrm{g} / \mathrm{mL}$ penicillin, $100 \mu \mathrm{g} / \mathrm{mL}$ streptomycin, $50 \mu \mathrm{g} / \mathrm{mL}$ kanamycin, $1 \mathrm{mM}$ sodium pyruvate, $2 \mathrm{mM} \mathrm{L-}$ glutamine, and non-essential amino acids, under atmospheric oxygen, at $37^{\circ} \mathrm{C}$. The medium was changed twice a week, and cells were passaged upon reaching confluence.

\section{Mild hypothermia}

Cells were cultured in the medium described above, under atmospheric oxygen, at $35^{\circ} \mathrm{C}$.

The Tel Aviv Sourasky Medical Center Institutional Animal Care and Use Committee approved all animal experiments, and all experiments were performed in accordance with institutional guidelines.

\section{Adipogenic differentiation}

Confluent cells were cultured in adipogenic medium, composed of DMEM, supplemented with 10\% FCS (Thermo Scientific HyClone), $10 \mu \mathrm{g} / \mathrm{mL}$ insulin, $1 \times 10^{-}$ ${ }^{6} \mathrm{M}$ dexamethasone, $0.5 \mathrm{mM}$ 3-isobutyl-1-methyl xanthine (IBMX), and $50 \mu \mathrm{M}$ indomethacin (all purchased from Sigma). After 21 days, the cells were fixed 
with $4 \%$ formalin (20 min, room temperature [RT]) and stained with $0.5 \%$ Oil Red O (10 min, RT) (Sigma). Cells were photographed with an Olympus IX71 microscope (Olympus, Tokyo, Japan) equipped with a DP73 camera. Oil Red O was then extracted with 4\% IGEPAL (Sigma) in isopropanol and quantified using a TECAN Infinite M200 plate reader (TECAN, Männedorf, Switzerland, emission $520 \mathrm{~nm}$ ).

\section{Osteogenic differentiation}

Confluent cells were cultured in StemPro osteogenesis differentiation medium (Gibco). The induction medium was replaced every 3-4 days. After 21 days, the cells were fixed with $4 \%$ formalin (20 min at RT) and stained with $2 \%$ Alizarin red (Sigma), pH 4.2 (10 min, at RT). Photographs were taken using an Olympus IX71 microscope with a DP73 camera. Alizarin red was extracted with extraction solution $(0.5 \mathrm{~N} \mathrm{HCL}$ and $5 \%$ sodium dodecyl sulfate) and quantified at $415 \mathrm{~nm}$ using a TECAN Infinite M200 plate reader (TECAN, Männedorf, Switzerland). Reads were normalized according to cell counts.

\section{Flow cytometry}

Apoptosis assessment by annexin/propidium iodide (PI) staining: Cells were stained using an annexin-APC/PI detection kit (BioLegend).

Labeled cells were analyzed using a BD FACS Canto II flow cytometer (Becton Dickinson). Data analysis was performed using the FlowJo software (Tree star, Ashland, OR, USA).

\section{Reactive oxygen species measurements}

Cells were trypsinized and incubated $\left(30 \mathrm{~min}, 37^{\circ} \mathrm{C}\right.$, in the dark) in PBS containing $10 \mu \mathrm{M} \mathrm{2}$ ',7-dichlorodihydrofluorescein diacetate (H2DCFDA) (Molecular Probes, Carlsbad, CA, USA). H2DCFDA was detected by flow cytometry in a BD FACS Canto II flow cytometer (BD Biosciences), and data were analyzed using the Flowjo software.

\section{Real-time PCR}

RNA was collected from cultured ASCs, during passages 2-5, using a Total RNA Mini Kit (Sigma). cDNA was prepared using M-MLV Reverse Transcriptase (Quanta Biosciences, Gaithersburg, MD, USA), according to the manufacturer's protocols. Real-time PCR was carried out using the perfeCTa SYBR mix (Quanta Biosciences) and processed using Step One Plus (Applied Biosystems, Foster City, CA, USA), with normalization to Rn18 s. All the primers used in the study are listed in Additional file 1: Table S1.

\section{CHIP array analysis}

Visceral ASCs were grown at $37^{\circ} \mathrm{C}$ (triplicates). In addition, visceral ASCs were grown at $35^{\circ} \mathrm{C}$ (duplicates). GenEltue Mammalian Total RNA Miniprep kit (Sigma-Aldrich) was used for RNA extraction. Samples were analyzed for gene expression using Affymetrix RaGene-2.1-st-v1 microarray at the Functional Genomics Laboratory, Sackler Faculty of Medicine, Tel Aviv University. Bioinformatics analysis was performed using Partek Genomics Suite (http://www.partek.com/partek-genomics-suite/). In short, cell files were normalized and $\log 2$ expression values were obtained, followed by ANOVA statistical evaluation. Differentially expressed genes were extracted using cutoffs $p$ value $<0.05$ and fold-change difference $=2$. A heatmap of differentially expressed genes was generated by Partek Genomics Suite.

All genes that were significantly different between visceral ASCs grown under $35^{\circ} \mathrm{C}$ and visceral ASCs grown under $37^{\circ} \mathrm{C}$ were analyzed by STRING database [41] protein-protein interaction tool (https://string-db.org/). Enriched processes are shown in Fig. 3.

\section{Statistical analysis}

The statistical significance of the results was determined using a two-tailed Student's $t$ test. $p$ values $<0.05$ were considered significant.

\section{Results}

Culture of rat visceral ASCs (vASCs) under $35^{\circ} \mathrm{C}$ attenuates oxidative stress, leading to reduced apoptosis and long-term expansion

Rat visceral ASCs (vASCs) were previously reported by us to repeatedly develop ROS over-accumulation at early passage and apoptosis-induced expansion arrest at passages 4-6 [14]. We therefore chose to examine the effect of reduced culture temperature on ROS production in these cells. In agreement with our previous report [14], vASCs culturing at $37^{\circ} \mathrm{C}$ resulted in ROS accumulation in correlation with NOX1 expression (Fig. 1A), a gradual increase in the number of annexin-positive apoptotic cells, reaching approximately $20 \%$ at passage 4 (Fig. 1B), and an expansion arrest at passages 4-6 (Fig. 1C). In contrast, vASC culturing at $35^{\circ} \mathrm{C}$, continuously from the time of extraction, was associated with attenuated ROS accumulation in correlation with NOX1 expression, a reduction in apoptosis rates, and long-term expansion of the cell population as compared to vASCs cultured at $37^{\circ} \mathrm{C}$ (Fig. 1A, B, and $\mathrm{C}$ respectively). Importantly, vASCs culturing at $35^{\circ} \mathrm{C}$ did not inhibit their proliferation rate, as demonstrated by a doubling time at passages 1-3 comparable to that of $37^{\circ} \mathrm{C}$ vASCs (Fig. 1D). Thus, vASCs cultured at $35^{\circ} \mathrm{C}$ display reduced ROS accumulation, which reduces their rate of apoptotic death and enables their long-term expansion. 


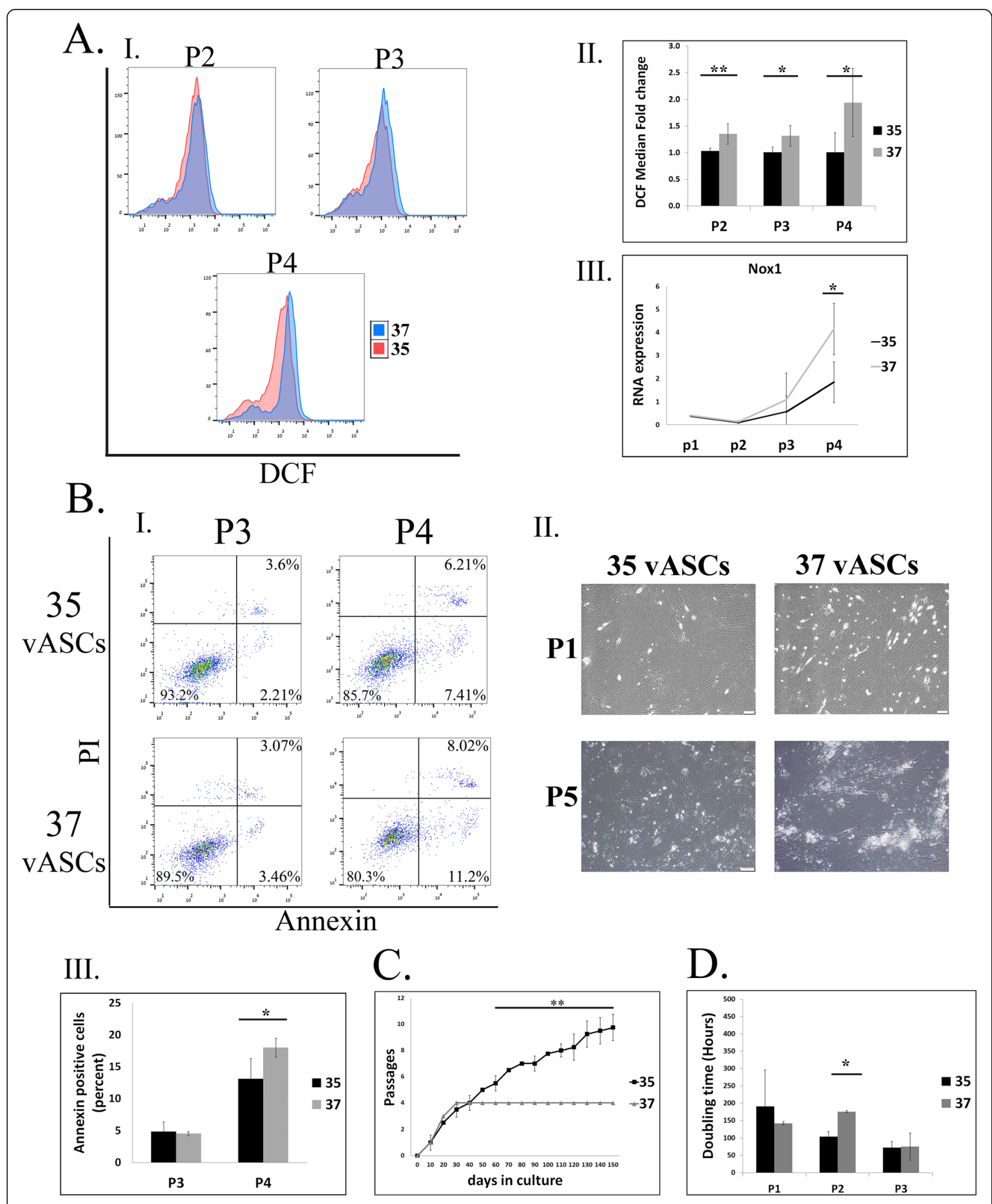

Fig. 1 (See legend on next page.) 
(See figure on previous page.)

Fig. 1 Culture of VASCs at $35^{\circ} \mathrm{C}$ attenuates NOX1-dependent oxidative stress and apoptosis, enabling long-term expansion. vASCs were propagated at $35^{\circ} \mathrm{C}$ or $37^{\circ} \mathrm{C}$. A ROS accumulation was detected by DCFDA staining and analyzed by flow cytometry at the indicated passages (P). (Al) Representative FACS analyses. (All) Summary results of three independent repeats at P2-4. Error bars represent SD. (Alll) qRT-PCR analysis of NOX1 RNA levels in cells grown at $35^{\circ} \mathrm{C}$ (black line) versus $37^{\circ} \mathrm{C}$ (gray line) at the indicated passages ( $n=$ two independent repeats). B The percentage of apoptotic cells at each passage of cells grown at $37^{\circ} \mathrm{C}$ and $35^{\circ} \mathrm{C}$ was determined by Pl/ Annexin staining, followed by FACS analysis. (BI) Representative FACS analyses. (BII) Images of representative $37^{\circ} \mathrm{C}$ and $35^{\circ} \mathrm{C}$ vASCS at P1 and P5. (BIII) Mean of FACs analyses by-passage rate of apoptosis in $37^{\circ} \mathrm{C}$ and $35^{\circ} \mathrm{C}$ vASC cultures ( $n=$ two independent repeats). C A growth curve comparing the ability of visceral ASCs to undergo long-term expansion at $37^{\circ} \mathrm{C}$ versus $35^{\circ} \mathrm{C}$ as evident by the number of passages reached against the time in culture in days ( $n=$ four independent repeats). Cells were passaged only when reaching confluence. Error bars represent standard deviation (SD). D The doubling time of $370 \mathrm{C}$ and $350 \mathrm{OC}$ VASC was compared ( $\mathrm{n}=$ two independent repeats). The doubling time of $37^{\circ} \mathrm{C}$ and $35^{\circ} \mathrm{C}$ vASC was compared ( $n=$ two independent repeats). Student's two-tailed $t$ test for equal variance: ${ }^{* *} p<0.01 ;{ }^{*} p<0.05$

\section{Culture under $35^{\circ} \mathrm{C}$ enhances vASC fat differentiation potential}

We previously described the low fat differentiation potential of vASCs compared to ASCs derived from subcutaneous fat, which correlated with measured levels of NOX1-induced oxidative stress [14]. As can be seen in Fig. 2, expansion of vASCs under $35^{\circ} \mathrm{C}$ culture conditions promoted a drastic increase in fat differentiation as compared to vASCs cultured at $37^{\circ} \mathrm{C}$ (Fig. 2A) but not of bone differentiation (Fig. 2B).
Gene array analysis identifies 110 genes significantly upor downregulated in $37^{\circ} \mathrm{C}$ compared to $35^{\circ} \mathrm{C}$ vASC

\section{cultures}

In pursuit of the molecular mechanisms responsible for the phenotypic differences between $37^{\circ} \mathrm{C}$ vASC and $35^{\circ} \mathrm{C}$ vASC cultures, we performed a comparative gene array analysis of vASCs grown under both culture conditions. The gene array analysis was performed on passage 3 cells, which preceded the stage at which $37^{\circ} \mathrm{C}$ vASC cultures underwent

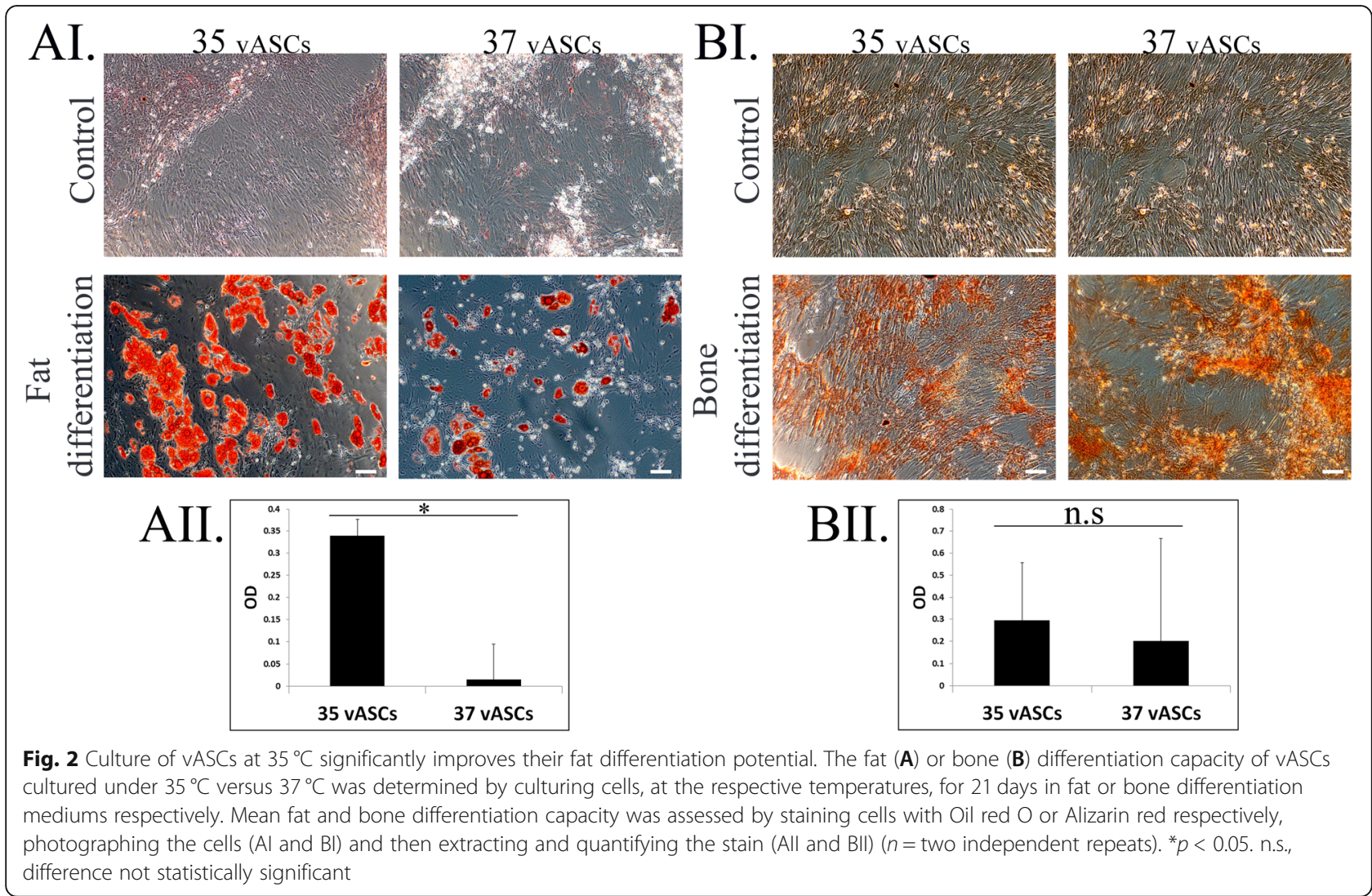




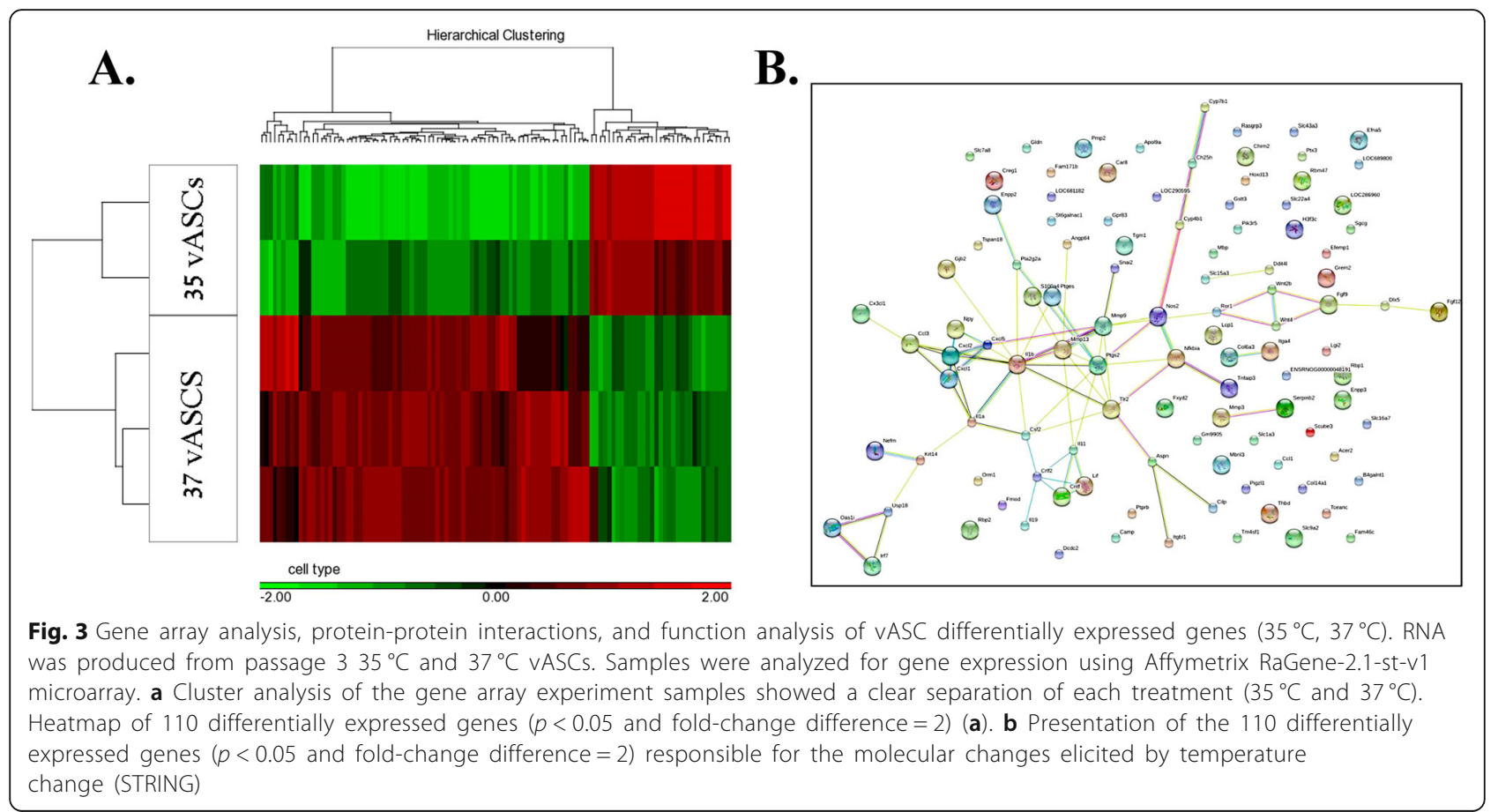

significant apoptosis and expansion arrest. The analysis categorized the $37^{\circ} \mathrm{C}$ vASCs and $35^{\circ} \mathrm{C}$ vASCs as two separate populations (Fig. 3a). The gene array analysis identified 110 genes that were significantly $(p<0.05)$ up- or downregulated $(>2$-fold change) in $35^{\circ} \mathrm{C}$ vASCs as compared to $37^{\circ} \mathrm{C}$ vASCs (Fig. 3a).
Function analysis of differentially expressed genes demonstrates a reduced inflammatory phenotype in $35^{\circ} \mathrm{C}$ vASCs

In order to further characterize the changes in gene expression observed between $35^{\circ} \mathrm{C}$ vASCs and $37^{\circ} \mathrm{C}$ vASCs, the 110 up/downregulated genes were analyzed using STRING database defining protein-protein

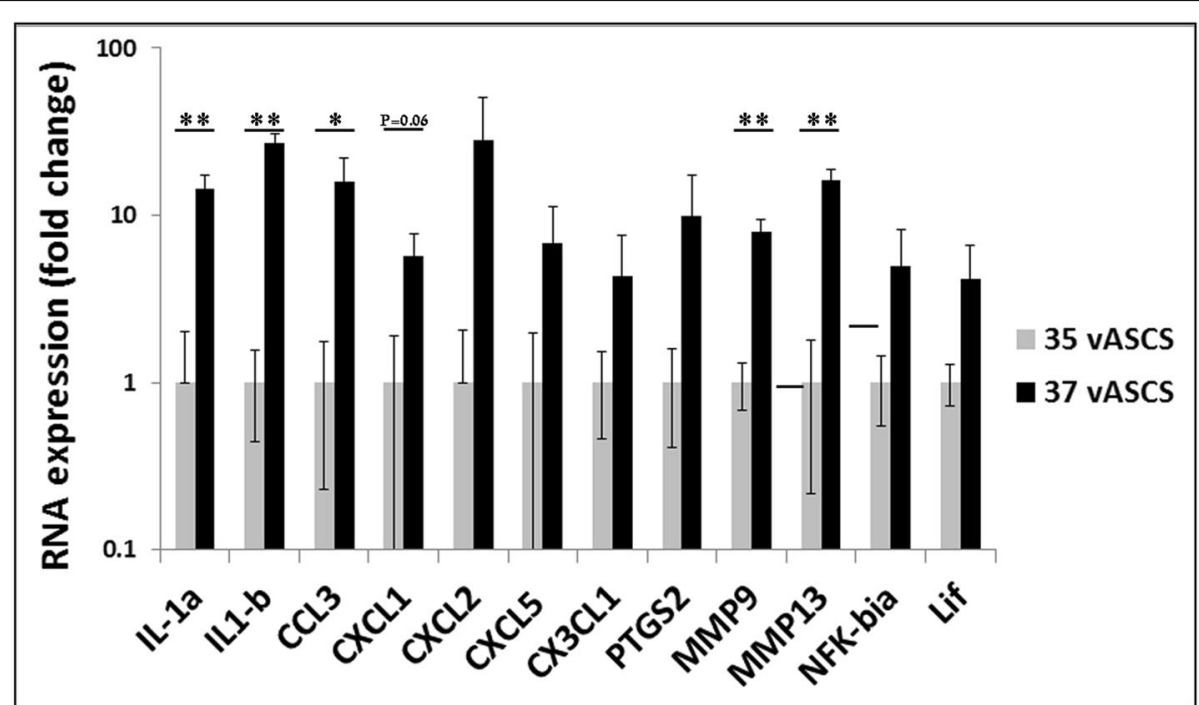

Fig. 4 qRT-PCR-based validation of genes highlighted in the functional cluster analysis. RNA was extracted from passage $337^{\circ} \mathrm{C}$ and $35^{\circ} \mathrm{C}$ vASCs, and the gene expression of the indicated genes was compared by qRT-PCR ( $n=2-3$ independent repeats). Gene expression was validated according to the differential expression in the gene array analysis 
interactions and functional enrichment of gene clusters (Fig. 3b). A drastic reduction in the expression level of a range of immune-related factors was noted in $35^{\circ} \mathrm{C}$ vASC cultures as compared to $37^{\circ} \mathrm{C}$ vASC cultures (Additional file 2: Table S2). An additional gene cluster termed "response to oxygen-containing compounds" containing, amongst other genes, important immune modulators showed reduced gene expression levels in $35^{\circ} \mathrm{C}$ vASCs as compared to $37^{\circ} \mathrm{C}$ vASCs (Additional file 2: Table S2). Interestingly, temperature reduction was also found to affect cell proliferation, differentiation, and wound healing potential (Additional file 2: Table S2), suggesting a possible influence of culture conditions on the regeneration potential of ASCs. The gene array results (Additional file 3: Table S3) were validated by performing qRT-PCR on 12 representative genes from all four gene groups; the differential gene expression between groups was preserved (Fig. 4).

\section{ROS accumulation in rat subcutaneous ASCs (scASCs) correlates with increased expression of pro-inflammatory cytokines}

The results presented thus far demonstrated the tendency of $37{ }^{\circ} \mathrm{C}$ vASC cultures to develop ROS overaccumulation/oxidative stress that was correlated with a shift toward a pro-inflammatory phenotype. We previously reported a reduced tendency of scASCs to accumulate ROS at passages 1-6 compared to vASCs [14]. However, As can be seen in Fig. 5A, rat scASCs cultured at normal culture conditions $\left(37^{\circ} \mathrm{C}\right)$ demonstrated increased ROS accumulation (Fig. 5A) and apoptosis (Fig. 5B) at late passages $(>10)$ compared to their early counterparts (passages 4-6). Thus, to verify the correlation between ROS accumulation and the development of a pro-inflammatory phenotype, we compared the pro-inflammatory phenotype of early versus late scASCs. As seen with vASCs, increased ROS accumulation at late scASC passages was associated with an increased pro-inflammatory phenotype (Fig. 5C).

\section{Culture of human subcutaneous ASCs at $35^{\circ} \mathrm{C}$ attenuates oxidative stress development, leading to reduced apoptosis without impairing expansion}

Clinically relevant human ASCs are generally produced from subcutaneous fat extracted by different liposuction techniques. Therefore, we decided to examine whether our findings in rat vASCs and scASCs also apply to human subcutaneous ASCs. To this end, we examined the effect of reduced culture temperature on the phenotype of subcutaneous ASCs by comparing their long-term expansion at $37^{\circ} \mathrm{C}$ and $35^{\circ} \mathrm{C}$. Increased ROS accumulation in $37^{\circ} \mathrm{C}$ compared to $35^{\circ} \mathrm{C}$ ASCs was already evident at passage 3 and was further enhanced with increasing passages (Fig. 6A). Importantly, however, the culture of ASCs at $35^{\circ} \mathrm{C}$ did not affect their expansion rate, as evident from cell quantities comparable to those of $37^{\circ} \mathrm{C}$ ASCs at passages $0-3$ (Fig. 6B). At passage 5, ROS overaccumulation in $37^{\circ} \mathrm{C}$ ASCs led also to their increased apoptosis as compared to $35^{\circ} \mathrm{C}$ ASCs (Fig. 6C). The correlation between ROS accumulation and the development of a pro-inflammatory phenotype was also demonstrated, with human ASCs cultured at $37^{\circ} \mathrm{C}$ exhibiting increased expression of pro-inflammatory cytokines (IL-1b, IL-1a, and IL-6) as compared to ASCs cultured at $35^{\circ} \mathrm{C}$ (Fig. 6D-F).

\section{Discussion}

We and others have previously described the tendency of ASCs to accumulate ROS during long-term culturing, leading to DNA damage, apoptosis, expansion arrest, and reduced fat differentiation potential $[12,14]$. In the current study, we showed, for the first time, that a $2{ }^{\circ} \mathrm{C}$ reduction in the culture temperature inhibits ROS overaccumulation in both human subcutaneous ASCs and rat vASCs, resulting in reduced apoptosis and improved long-term expansion. In addition, the culture of rat vASCs at $35^{\circ} \mathrm{C}$ led also to their enhanced fat differentiation compared to $37^{\circ} \mathrm{C}$ vASCs. Gene array analysis demonstrated reduced expression of many immune modulators in $35^{\circ} \mathrm{C}$ versus $37^{\circ} \mathrm{C}$ ASC cultures, indicating a reduced inflammatory phenotype under $35^{\circ} \mathrm{C}$ culture conditions. Functional analysis further identified reduced expression of a cluster of "response to oxygencontaining compounds" genes in $35^{\circ} \mathrm{C}$ vASCs compared to $37^{\circ} \mathrm{C}$ vASCs, correlating the increased inflammatory phenotype in $37^{\circ} \mathrm{C}$ vASCs with their increased ROS production and oxidative stress. The correlation between ROS overproduction and the pro-inflammatory phenotype was further corroborated by the observed increased expression of pro-inflammatory genes in both human and rat subcutaneous ASCs in response to ROS accumulation. Thus, reducing culture temperature can enhance ASC quality and quantity and prevent culture-induced oxidative stress and cell damage, which may all impact their clinical effectiveness.

Elevated oxygen concentrations are known to stimulate increased mitochondrial ROS production by promoting higher ROS leakage from the respiratory chain [9]. In turn, the increased oxygen levels during the transition of MSC progenitor cells from their physiological niche conditions (2-8\% oxygen) to culture conditions (atmospheric oxygen 21\%) trigger enhanced mitochondrial ROS production and ROS over-accumulation [10-14]. One viable approach to attenuate mitochondrial ROS accumulation during MSC culture is reducing culture temperature, which, in turn, will decrease cellular metabolism as 


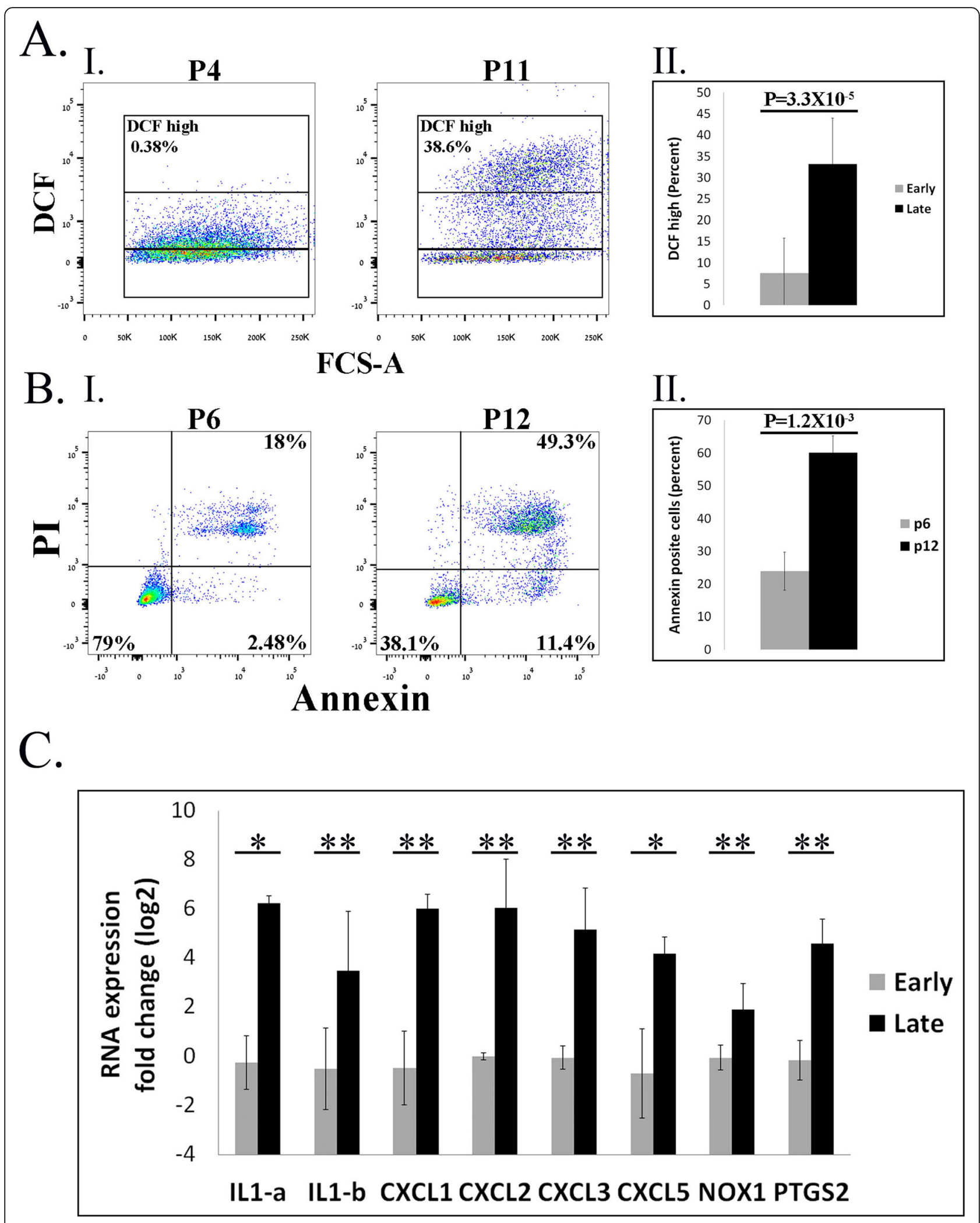


(See figure on previous page.)

Fig. 5 ROS accumulation correlates with the development of a pro-inflammatory phenotype in rat sCASCs. Rat scASCs were propagated at $37^{\circ} \mathrm{C}$, and early $p \leq 6$ and late $p \geq 10$ cells were harvested and analyzed. A ROS accumulation was detected by DCFDA staining and analyzed by flow cytometry at the indicated passages (P). (Al) Representative FACS analyses. (All) A summary of two independent repeats of the FACS analysis. B Comparison of the percentage of apoptotic cells in early versus late passage of cells grown at $37{ }^{\circ} \mathrm{C}$ and $35^{\circ} \mathrm{C}$, as determined by PI/Annexin staining, followed by FACS analysis. (BI) Representative FACS analyses. (BII) A summary of two independent repeats. C RNA was extracted from early and late passages of $37^{\circ} \mathrm{C}$ sCASCs, and gene expression of the indicated genes was compared by qRT-PCR $(n=2$ independent repeats). Data are presented as the mean \pm standard deviation. ${ }^{* *} p<0.01 ;{ }^{*} p<0.05$

was reported for various cell types [33-36]. Reduced ROS accumulation in $32{ }^{\circ} \mathrm{C}$ bone marrow-derived MSC cultures was previously reported [38]. Yet, the culture of both bone marrow-derived MSCs and additional cell types at temperatures below $34{ }^{\circ} \mathrm{C}$ was also reported to inhibit cell proliferation, [35, 38] hindering cell expansion. In contrast, culture at temperatures between 34 and $35.5^{\circ} \mathrm{C}$ was reported to promote similar cell proliferation rates as cultures at $37^{\circ} \mathrm{C}$, despite a significant reduction in cellular oxygen and glucose consumption [37, 39]. We therefore chose to assess long-term expansion of ASCs under mild hypothermia $\left(35^{\circ} \mathrm{C}\right)$. These culture conditions were able to salvage both rat and human ASCs from ROS overproduction and consequential apoptosis. In rat vASCs, reducing culture temperature from 37 to $35^{\circ} \mathrm{C}$ also prevented apoptosis-induced expansion arrest that was previously observed in $37^{\circ} \mathrm{C}$ vASCs, enabling long-term expansion, without affecting proliferation rates; the $35^{\circ} \mathrm{C}$ vASC cultures proliferated just as effectively as passage $0-337^{\circ} \mathrm{C}$ vASC cultures prior to expansion arrest. Similar to vASCs, no reduction in the proliferation of $35^{\circ} \mathrm{C}$ human ASCs was observed compared to $37^{\circ} \mathrm{C}$ human ASCs.

We previously reported that ROS overproduction in vASCs was accompanied by increased expression of NOX1 but not of NOX2 or NOX4. NOX family members are an important source of intracellular ROS pointing to NOX1 involvement in ROS accumulation [14]. This was verified when vASCs that were grown under $3 \%$ oxygen conditions and expanded long term displayed reduced NOX1 expression and decreased ROS accumulation [14]. NOX1 involvement in vASC cytostasis was reaffirmed when cells that were expanded under normal oxygen conditions $(21 \%)$ in the presence of a specific NOX1 inhibitor, ML171, demonstrated reduced ROS accumulation, reduced apoptosis, and long-term expansion [14]. In the current study, we demonstrated that vASC culturing at $35^{\circ} \mathrm{C}$ was associated with an attenuated ROS accumulation in correlation with NOX1 expression, a reduction in apoptosis rates, and long-term expansion of the cell population as compared to vASCs cultured at $37^{\circ} \mathrm{C}$. This indicates that ROS decreased accumulation in $35^{\circ} \mathrm{C}$ vASCs compared to $37^{\circ} \mathrm{C}$ vASCs resulted, at least in part, from the reduction of NOX1 expression under $35^{\circ} \mathrm{C}$ culture conditions.
We previously showed a direct correlation between the reduction of ROS levels and fat differentiation potential in $37^{\circ} \mathrm{C}$ vASC cultures upon administration of a NOX1-specific inhibitor [14]. Enhanced fat differentiation potential in correlation with reduced ROS accumulation was similarly observed in scASCs [14]. In the current study, reduced culture temperature increased vASC fat differentiation capabilities in correlation with reduced ROS accumulation. It is thus reasonable to assume that the markedly improved fat differentiation potential of $35^{\circ} \mathrm{C}$ vASC cultures was a direct result of reduced ROS production. It has been generally agreed that ROS accumulation positively regulates fat differentiation [42], although the exact source of ROS during adipogenesis is still controversial. Thus, unlike the temporal physiological increase in ROS levels, previously reported during fat differentiation, the increased chronic and toxic accumulation of ROS in $37^{\circ} \mathrm{C}$ vASC cultures seems to disrupt many physiological processes, including fat differentiation processes.

Comparison of the gene expression pattern of $37^{\circ} \mathrm{C}$ versus $35^{\circ} \mathrm{C}$ ASCs revealed an increased expression of various positive modulators of immune processes, including the pivotal IL-1a and IL-1b cytokines and various chemokines in $37^{\circ} \mathrm{C}$ ASCs. Thus, culturing ASCs under slightly hypothermic conditions reduces their inflammatory phenotype as compared to $37^{\circ} \mathrm{C}$ ASCs. In recent years, MSCs have gained much attention due to their potential application as immunomodulators for the treatment of immune-mediated diseases such as autoimmune diseases, graft-versus-host disease (GvHD), and inflammatory diseases [43]. In such cases, it would seem that the reduced inflammatory phenotype of $35^{\circ} \mathrm{C}$ vASCs would provide a clinical advantage.

In an earlier study [14], we showed that early-passage scASCs cultured at $37^{\circ} \mathrm{C}$ generated less ROS as compared to $37^{\circ} \mathrm{C}$ vASCs and consequently demonstrated reduced apoptosis and enhanced expansion and fat differentiation than the former [14]. In the current study, similar to scASCs, vASCs cultured at $35^{\circ} \mathrm{C}$ demonstrated reduced ROS accumulation that correlated with their reduced apoptosis and enhanced expansion and fat differentiation compared to $37^{\circ} \mathrm{C}$ vASCs. Thus, we speculate that most of the changes in gene expression levels measured in $35^{\circ} \mathrm{C}$ vASCs occurred in response to 


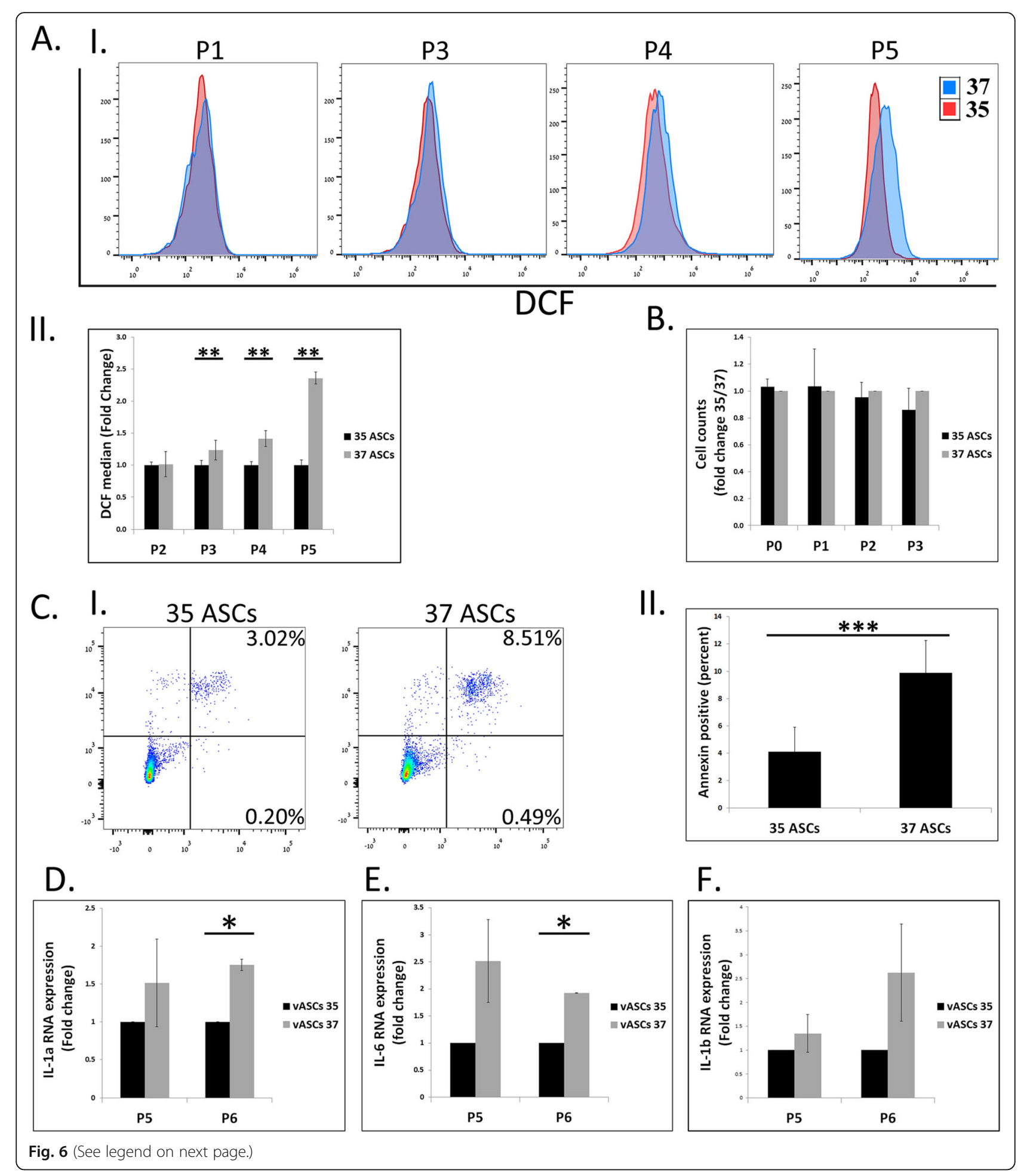


(See figure on previous page.)

Fig. 6 Culture of human subcutaneous ASCs at $35^{\circ} \mathrm{C}$ attenuates ROS accumulation and apoptosis without affecting cell expansion. Human ASCs were isolated from lipoaspirates, seeded, and immediately cultured either at a normal culture temperature $\left(37^{\circ} \mathrm{C}\right)$ or at a mildly reduced temperature $\left(35^{\circ} \mathrm{C}\right)$. A Comparison of ROS accumulation between ASCs isolated from the same lipoaspirate and grown at either $37^{\circ} \mathrm{C}$ or $35^{\circ} \mathrm{C}$ was performed by DCFDA staining and its analysis by flow cytometry, at the indicated passages (P). (Al) Representative FACS analyses. (All) Summary of three independent repeats from three different patients, at P2-4, and one repeat at P5. Data are presented as the mean \pm standard deviation. B Cells were counted at each passage and reseeded at equal numbers. Cell counts at each passage are presented $(n=4$ independent repeats). $\mathbf{c}$ Comparison of the percentage of apoptotic ASCs at each passage of cells grown at $37^{\circ} \mathrm{C}$ and $35^{\circ} \mathrm{C}$ was performed by Pl/Annexin staining, followed by FACS analysis. (CI) A representative FACS analysis. (CII) Summary results of three biological repeats from one patient at P5. Similar differences in the level of apoptosis between 37 and $35^{\circ} \mathrm{C}$ ASC cultures were obtained from three independent patients but at different passages. D-F RNA was extracted at different passages and the level of expression of the indicated genes was compared between 37 and $35^{\circ} \mathrm{C}$ ASCs $(n=2)$. Data are presented as the mean \pm standard deviation. ${ }^{* *} p<0.001 ;{ }^{* *} p<0.01 ;{ }^{*} p<0.05$

reduced ROS production in these cells. Accordingly, analysis of the gene array results also uncovered enhanced expression of genes associated with response to oxygen, the majority of which were immune modulators or genes involved in immune regulation, in $37^{\circ} \mathrm{C}$ vASCs. Therefore, since $35^{\circ} \mathrm{C}$ culture conditions also led to a significant reduction in ROS accumulation in vASCs, we wanted to determine whether ROS accumulation played a direct role in the development of the proinflammatory phenotype of $37^{\circ} \mathrm{C}$ vASCs. To this end, we compared the expression of pro-inflammatory immune modulators between early- and late-passage $(>10)$ rat scASCs cultured at $37^{\circ} \mathrm{C}$, which display increased oxidative stress at later passages. Indeed, a significant increase in the pro-inflammatory phenotype was found in late- compared to early-passage scASCs, in correlation with oxidative stress enhancement, indicating that ROS accumulation and not culture temperature was responsible for the phenotypic shift. In accordance, $35^{\circ} \mathrm{C} \mathrm{hu}$ man ASCs cultures demonstrated significantly reduced ROS production in correlation with the reduced expression of the pro-inflammatory cytokines IL-1a, IL-1b, and IL-6 compared to $37^{\circ} \mathrm{C}$ human ASCs. In conclusion, we propose that the development of intracellular oxidative stress in ASC cultures elicits increased expression of various immune modulators, with a tendency toward a pro-inflammatory phenotype.

\section{Conclusions}

Thus, a mild temperature shift in ASC cultures can induce profound effects on their in vitro phenotype without affecting their proliferation rate, possibly affecting the cells' in vivo clinical efficacy. Given their highly plastic nature, the culture conditions of MSCs, in general, and of ASCs, in particular, must be strictly controlled to avoid inter-batch variability. In addition, given the undisputed harmful effect of oxidative stress on cells, we speculate that a mildly reduced culture temperature may serve as a simple means of preventing ROS overproduction in ASCs.

\section{Supplementary information}

Supplementary information accompanies this paper at https://doi.org/10. 1186/s13287-019-1542-0.

Additional file 1: Table S1. Primer list.

Additional file 2: Table S2. Function analysis of the differentially expressed genes between $37^{\circ} \mathrm{C}$ and $35^{\circ} \mathrm{C}$ ASCs.

Additional file 3: Table S3. Gene array results of the main proinflammatory genes appearing in the function analysis of the differentially expressed genes between $37^{\circ} \mathrm{C}$ and $35^{\circ} \mathrm{C}$ ASCs.

\section{Abbreviations}

ASCs: Adipose-derived stem cells; DMEM: Dulbecco's modified Eagle's medium; FCS: Fetal calf serum; GvHD: Graft-versus-host disease; H2DCFDA: 2',7-Dichlorodihydrofluorescein diacetate; MSCs: Mesenchymal stem cells; PI: Propidium iodide; ROS: Reactive oxygen species; RT: Room temperature; sCASCs: Subcutaneous ASCs; SVF: Stromal vascular fraction; vASCs: Rat visceral ASCs

\section{Acknowledgements}

Not applicable

\section{Authors' contributions}

GT performed most of the experimental work presented on rat ASCs. IS performed most of the experimental presented on human ASCs and was incremental in the analysis of FACS data. MS was involved in rat ASC longterm culture and in sample preparation for the gene array analysis. MPC performed the analysis of the gene array data. IG was involved in the experiments presented on rat sCASCs and performed the qRT-PCR analysis. NS and EG supervised all the experimental work performed and in getting the funding for the research. NS and GT prepared the manuscript. All authors read and approved the final manuscript.

\section{Funding}

We have no funding resources to declare.

\section{Availability of data and materials}

The datasets used and/or analyzed during the current study are available from the corresponding author on reasonable request.

\section{Ethics approval and consent to participate}

The Tel Aviv Sourasky Medical Center Institutional Animal Care and Use Committee approved all animal experiments.

All procedures were performed in accordance with the Declaration of Helsinki and approved by the ethics committee of Tel Aviv Sourasky Medical Center. Written, informed consent was obtained from all patients in advance.

\section{Consent for publication}

Not applicable

Competing interests

The authors declare that they have no competing interests. 


\section{Author details}

'The Department of Plastic and Reconstructive Surgery, Tel Aviv Sourasky Medical Center, Tel Aviv, Israel. ${ }^{2}$ The Bioinformatics Unit George S. Wise Faculty of Life Sciences, Tel Aviv University, Tel Aviv, Israel. ${ }^{3}$ The Department of Plastic and Reconstructive Surgery, Tel Aviv Sourasky Medical Center, affiliated with the Sackler Faculty of Medicine, Tel Aviv University, Weizmann 6, Tel Aviv, Israel.

\section{Received: 23 July 2019 Revised: 10 December 2019}

Accepted: 26 December 2019 Published online: 23 January 2020

\section{References}

1. Uccelli A, Moretta L, Pistoia V. Mesenchymal stem cells in health and disease. Nat Rev Immunol. 2008;8(9):726-36

2. Bourin P, Bunnell BA, Casteilla L, Dominici M, Katz AJ, March KL, et al. Stromal cells from the adipose tissue-derived stromal vascular fraction and culture expanded adipose tissue-derived stromal/stem cells: a joint statement of the International Federation for Adipose Therapeutics and Science (IFATS) and the International Society for Cellular Therapy (ISCT). Cytotherapy. 2013;15(6):641-8.

3. Zuk PA, Zhu M, Mizuno H, Huang J, Futrell JW, Katz AJ, et al. Multilineage cells from human adipose tissue: implications for cell-based therapies. Tissue Eng. 2001;7(2):211-28.

4. Oliveira PH, Silva CL, Cabral J. Concise review: genomic instability in human stem cells: current status and future challenges. Stem Cells. 2014;32(11): 2824-32.

5. Brown DI, Griendling KK. Nox proteins in signal transduction. Free Radic Biol Med. 2009;47(9):1239-53.

6. Circu ML, Aw TY. Reactive oxygen species, cellular redox systems, and apoptosis. Free Radic Biol Med. 2010;48(6):749-62.

7. Giorgio M, Trinei M, Migliaccio E, Pelicci PG. Hydrogen peroxide: a metabolic by-product or a common mediator of ageing signals? Nat Rev Mol Cell Biol. 2007:8(9):722-8

8. Mohyeldin A, Garzón-Muvdi T, Quiñones-Hinojosa A. Oxygen in stem cell biology: a critical component of the stem cell niche. Cell Stem Cell. 2010; 7(2):150-61

9. Baez A, Shiloach J. Effect of elevated oxygen concentration on bacteria, yeasts, and cells propagated for production of biological compounds. Microb Cell Factories. 2014;13(1):181.

10. Bétous R, Renoud ML, Hoede C, Gonzalez I, Jones N, Longy M, et al. Human adipose-derived stem cells expanded under ambient oxygen concentration accumulate oxidative DNA lesions and experience procarcinogenic DNA replication stress. Stem Cells Transl Med. 2017;6(1):68-76.

11. Boregowda SV, Krishnappa V, Chambers JW, Lograsso PV, Lai WT, Ortiz LA, et al. Atmospheric oxygen inhibits growth and differentiation of marrowderived mouse mesenchymal stem cells via a p53-dependent mechanism: implications for long-term culture expansion. Stem Cells. 2012;30(5):975-87.

12. Estrada J, Albo C, Benguria A, Dopazo A, Lopez-Romero P, Carrera-Quintanar $L$, et al. Culture of human mesenchymal stem cells at low oxygen tension improves growth and genetic stability by activating glycolysis. Cell Death Differ. 2012;19(5):743-55.

13. Kim J-W, Tchernyshyov I, Semenza GL, Dang CV. HIF-1-mediated expression of pyruvate dehydrogenase kinase: a metabolic switch required for cellular adaptation to hypoxia. Cell Metab. 2006:3(3):177-85.

14. Sela M, Tirza G, Ravid O, Volovitz I, Solodeev I, Friedman O, et al. NOX1induced accumulation of reactive oxygen species in abdominal fat-derived mesenchymal stromal cells impinges on long-term proliferation. Cell Death Dis. 2015;6(4):e1728.

15. Lengner CJ, Gimelbrant AA, Erwin JA, Cheng AW, Guenther MG, Welstead $\mathrm{GG}$, et al. Derivation of pre-X inactivation human embryonic stem cells under physiological oxygen concentrations. Cell. 2010;141(5):872-83.

16. Mathieu J, Zhou W, Xing Y, Sperber H, Ferreccio A, Agoston Z, et al. Hypoxia-inducible factors have distinct and stage-specific roles during reprogramming of human cells to pluripotency. Cell Stem Cell. 2014;14(5): 592-605.

17. Yoshida Y, Takahashi K, Okita K, Ichisaka T, Yamanaka S. Hypoxia enhances the generation of induced pluripotent stem cells. Cell Stem Cell. 2009;5(3): 237-41.

18. Basciano L, Nemos C, Foliguet B, de Isla N, de Carvalho M, Tran N, et al. Long term culture of mesenchymal stem cells in hypoxia promotes a genetic program maintaining their undifferentiated and multipotent status. BMC Cell Biol. 2011;12(1):12

19. Choi JR, Pingguan-Murphy B, Abas WABW, Azmi MAN, Omar SZ, Chua KH, et al. Impact of low oxygen tension on stemness, proliferation and differentiation potential of human adipose-derived stem cells. Biochem Biophys Res Commun. 2014:448(2):218-24.

20. Choi JR, Yong KW, Safwani WKZW. Effect of hypoxia on human adiposederived mesenchymal stem cells and its potential clinical applications. Cell Mol Life Sci. 2017:74(14):2587-600.

21. Fehrer C, Brunauer R, Laschober G, Unterluggauer H, Reitinger S, Kloss F, et al. Reduced oxygen tension attenuates differentiation capacity of human mesenchymal stem cells and prolongs their lifespan. Aging Cell. 2007;6(6): 745-57.

22. Grayson WL, Zhao F, Bunnell B, Ma T. Hypoxia enhances proliferation and tissue formation of human mesenchymal stem cells. Biochem Biophys Res Commun. 2007;358(3):948-53.

23. Saller MM, Prall WC, Docheva D, Schönitzer $V$, Popov $T$, Anz D, et al. Increased stemness and migration of human mesenchymal stem cells in hypoxia is associated with altered integrin expression. Biochem Biophys Res Commun. 2012;423(2):379-85.

24. Valorani M, Montelatici E, Germani A, Biddle A, D'alessandro D, Strollo R, et al. Pre-culturing human adipose tissue mesenchymal stem cells under hypoxia increases their adipogenic and osteogenic differentiation potentials. Cell Prolif. 2012;45(3):225-38.

25. Denu RA, Hematti P. Effects of oxidative stress on mesenchymal stem cell biology. Oxidative Med Cell Longev. 2016; Article ID 2989076:9.

26. Cai L, Stevenson J, Geng X, Peng C, Ji X, Xin R, et al. Combining normobaric oxygen with ethanol or hypothermia prevents brain damage from thromboembolic stroke via PKC-Akt-NOX modulation. Mol Neurobiol. 2016. p. 1 15.

27. Ning $X-H$, Xu C-S, Song YC, Xiao Y, Hu Y-J, Lupinetti FM, et al. Hypothermia preserves function and signaling for mitochondrial biogenesis during subsequent ischemia. Am J Phys Heart Circ Phys. 1998;274(3):H786-H93.

28. Tissier R, Chenoune M, Pons S, Zini R, Darbera L, Lidouren F, et al. Mild hypothermia reduces per-ischemic reactive oxygen species production and preserves mitochondrial respiratory complexes. Resuscitation. 2013;84(2):249-55.

29. Zhao H, Steinberg G. Limited therapeutic time windows of mild-tomoderate hypothermia in a focal ischemia model in rat. Stroke Res Treat. 2011;2011.

30. Dave KR, Christian SL, Perez-Pinzon MA, Drew KL. Neuroprotection: lessons from hibernators. Comp Biochem Physiol B: Biochem Mol Biol. 2012;162(1):1-9.

31. Brown JC, Chung DJ, Belgrave KR, Staples JF. Mitochondrial metabolic suppression and reactive oxygen species production in liver and skeleta muscle of hibernating thirteen-lined ground squirrels. Am J Phys Regul Integr Comp Phys. 2012;302(1):R15-28.

32. Brown JC, Staples JF. Mitochondrial metabolic suppression in fasting and daily torpor: consequences for reactive oxygen species production. Physiol Biochem Zool. 2011;84(5):467-80

33. Chuppa S, Tsai YS, Yoon S, Shackleford S, Rozales C, Bhat R et al. Fermentor temperature as a tool for control of high-density perfusion cultures of mammalian cells. Biotechnol Bioeng. 1997:55(2):328-38.

34. Jorjani P, Ozturk SS. Effects of cell density and temperature on oxygen consumption rate for different mammalian cell lines. Biotechnol Bioeng. 1999:64(3):349-56.

35. Moore A, Mercer J, Dutina G, Donahue CJ, Bauer KD, Mather JP, et al. Effects of temperature shift on cell cycle, apoptosis and nucleotide pools in $\mathrm{CHO}$ cell batch cultues. Cytotechnology. 1997;23(1-3):47-54.

36. Weidemann R, Ludwig A, Kretzmer G. Low temperature cultivation-a step towards process optimisation. Cytotechnology. 1994;15(1-3):111-6.

37. Bloemkolk JW, Gray MR, Merchant F, Mosmann TR. Effect of temperature on hybridoma cell cycle and MAb production. Biotechnol Bioeng. 1992;40(3): 427-31

38. Stolzing A, Scutt A. Effect of reduced culture temperature on antioxidant defences of mesenchymal stem cells. Free Radic Biol Med. 2006:41(2):326-38.

39. Sureshkumar G, Mutharasan R. The influence of temperature on a mousemouse hybridoma growth and monoclonal antibody production. Biotechnol Bioeng. 1991;37(3):292-5.

40. Dexter TM, Allen TD, Lajtha L. Conditions controlling the proliferation of haemopoietic stem cells in vitro. J Cell Physiol. 1977;91(3):335-44.

41. Szklarczyk D, Morris $\mathrm{H}$, Cook H, Kuhn M, Wyder S, Simonovic $\mathrm{M}$, et al. The STRING database in 2017: quality-controlled protein-protein association 
networks, made broadly accessible. Nucleic Acids Res. 2016;45(D1):D362D368.

42. Liu G-S, Chan EC, Higuchi M, Dusting GJ, Jiang F. Redox mechanisms in regulation of adipocyte differentiation: beyond a general stress response. Cells. 2012; (4):976-93.

43. Zhao Q, Ren $\mathrm{H}$, Han Z. Mesenchymal stem cells: immunomodulatory capability and clinical potential in immune diseases. J Cell Immunother. 2016;2(1):3-20

\section{Publisher's Note}

Springer Nature remains neutral with regard to jurisdictional claims in published maps and institutional affiliations.

Ready to submit your research? Choose BMC and benefit from:

- fast, convenient online submission

- thorough peer review by experienced researchers in your field

- rapid publication on acceptance

- support for research data, including large and complex data types

- gold Open Access which fosters wider collaboration and increased citations

- maximum visibility for your research: over $100 \mathrm{M}$ website views per year

At BMC, research is always in progress.

Learn more biomedcentral.com/submissions 